\title{
Amelioration by chlorophytum borivilianum upon arsenic induced oxidative stress in Swiss albino mice
}

\author{
Garima Sharma, Madhu Kumar* \\ Cell and Molecular Biology Laboratory, Department of Zoology, Centre for Advanced Studies, \\ University of Rajasthan, Jaipur 302004, India \\ *Corresponding author E-mail: mamsjpr@yahoo.com
}

\begin{abstract}
Background: Arsenic, a major water pollutant in India, produces toxic effects on male reproductive system due to oxidative stress. Arsenic contaminated drinking water causes several health problems such as Blackfoot disease, hypertension, diabetes mellitus, disturbances in the nervous system and cancers of liver, kidney, lung and bladder in humans.

Aim: This study accessed the efficacy of Chlorophytum borivilianum in reducing arsenic-induced biochemical and nucleic acid damages in mice testis.

Methods: A different group of adult Swiss albino mice was made such as control group, C. borivilianum group, sodium arsenite group and combination group. For antioxidant activity, ABTS radical cation decolorization assay was done. Body and testis weight, protein, sialic acid, ATPase activity, DNA and RNA content in the testis were also estimated.

Results: Animals exposed to sodium arsenite at the dose of $4.0 \mathrm{mg} / \mathrm{kg}$ b.wt. showed significant decrease $(\mathrm{p}<0.001)$ in testicular protein, sialic acid, ATPase activity, DNA and RNA content indicate DNA damage and apoptosis whereas combination group showed a significant increase in all the parameters.

Conclusion: The results thus led us to conclude that administration of C. borivilianum at the dose of $800 \mathrm{mg} / \mathrm{kg} \mathrm{b}$.wt. Significantly protects against arsenic-induced oxidative stress.
\end{abstract}

Keywords: ABTS Assay; Atpase; DNA; Oxidative Stress; Protein; Sialic Acid.

\section{Introduction}

Arsenic is a naturally occurring metalloid with potent toxic and mutagenic effects (Klein et al., 2007). It is present ubiquitously in the environment and releases from both natural and man-made sources (Erbanova et al., 2008). Humans are exposed to arsenic by ingestion of contaminated water, food and drugs or inhalation from burning of arsenic contaminated coal, semiconductor and glass manufacturing sites (Ali and Ali, 2010). Drinking water may be contaminated with arsenic from arsenical pesticide, natural mineral deposits or improperly disposed arsenical chemical (Guha Mazumder, 2008). Contamination of drinking water is a major health problem in certain areas including parts of Bangladesh, United States, Taiwan, Mexico, Japan and India where the arsenic concentration exceeds the WHO's drinking water provisional guideline value $10 \mu \mathrm{g} / \mathrm{L}$ (Kokilavani et al., 2005). Chronic exposure has been linked with a myriad of possible health effects, including skin lesions, hypertension, cardiovascular disease, pulmonary disease, reproductive (Sharma and Kumar, 2011; 2012) and neurological dysfunctions, hematological changes, and malignancies of the skin and internal organs (Gopalkrishnan and Rao, 2006; Santra et al., 2007). Oxidative stress has been proposed as a plausible general mode of action for arsenic toxicity (Sharma et al., 2009). Oxidative stress is characterized by generation of several ROS, such as superoxide anion, hydroxyl radical, hydrogen peroxide, singlet oxygen, peroxyl radical and nitric oxide (Vizcaya-Ruiz et al., 2009). Among these, the hydroxyl radical is the most toxic because it easily passes through membrane barriers to the cell's nucleus and strongly reacts mutagenically with DNA (Robertson et al., 2003). Arsenic induced formation of ROS and subsequent depletion of antioxidant cell defenses can result in disruption of the antioxidant/prooxidant equilibrium in mammalian tissues (Jomova et al., 2011). Metabolic disorders, hypertrophy of adrenal glands (Biswas et al., 1994) inhibition of the activity of testicular steroidogenic enzymes (Sarkar et al., 2003) and a reduction in the weight of the testis and accessory sex organs (Sarkar et al., 1991) are associated with exposure to arsenics. Toxicity of such agents in the testis may lead to testicular dysfunction, arrest of spermatogenesis and production of abnormal sperms (Peltola et al., 1994).

For the amelioration of toxicological effects of environmental toxicant especially heavy metals, natural products obtained from plants are positively used. Chlorophytum borivilianum Sant. F. (Liliaceae) also known as 'Safed Musli' is a traditional rare Indian medicinal herb which has many therapeutic applications in Ayurvedic, Unani, Homeopathic and Allopathic system of medicine (Vijaya and Chavan, 2009).Root is used as aphrodisiac, diuretic, astringent, useful in dysentery, as an antidiabetic and as appetizing agent (Chetty and Rao, 1989). It deals with the proper modulation of neuro-endocrino- immunological systems (Patwardhan et al., 2005). Its activity ranges from improvement in mental acuity, maintenance of homeostasis, prevention of degenerative disease, antioxidant and improves in failing sexual function (Kaushik, 2005) Its root contains steroidal and triterpenoidal saponins, sapogenins and fructans which act as therapeutic agents and play vital role in many therapeutic applications (Thakur and 
Dixit, 2008). It is a source of alkaloids, vitamins, proteins, carbohydrates, steroids, saponins, potassium, calcium, magnesium, phenol, resins, mucilage, and polysaccharides and also contains high quantity of simple sugars, mainly sucrose, glucose, fructose, galactose, mannose and xylose (Thakur et al., 2009). The aim of the present study was, therefore undertaken to investigate the modulatory role of Chlorophytum borivilianum against arsenic induced biochemical and nucleic acid damages.

\section{Materials and methods}

\subsection{Test system}

Adult male Swiss albino mice (6-8weeks old, weighing $25 \pm 2 \mathrm{~g}$ ) maintained in the animal house as an inbred colony (Procured from IVRI, Izatnagar, India) under controlled conditions of temperature $\left(25 \pm 2^{\circ} \mathrm{C}\right)$, relative humidity $(50 \pm 15 \%)$ and normal photoperiod ( $12 \mathrm{~h}$ light and $12 \mathrm{~h}$ dark). The animals were housed in standard polypropylene laboratory cages containing 5-cm deep layer of sawdust bedding. Mice were given standard mice feed (Hindustan Lever Ltd., India) and tapwater adlibitum. Once in a fortnight tetracycline water was given as a preventive measure against infection. The ethical committee of Department of Zoology, University of Rajasthan, Jaipur (India) has approved to carry out the experimental protocol.

\subsection{Test chemical and plant material}

Arsenic in the form of $\mathrm{NaAsO}_{2}$ (mol. wt. 129.9) was obtained from standard commercial suppliers [Himedia, Mumbai, India Ltd.]. The roots of $\mathrm{C}$. borivilianum were collected from the market and it was identified (RUBL No.19902) from the herbarium of Department of Botany, University of Rajasthan, Jaipur, India. The animals were administered C. borivilianum root extract dissolved in DDW orally up to 30 days $(100,200,400,800 \mathrm{mg} / \mathrm{kg}$ b.wt.) and LPO and GSH contents were measured in the liver. The optimum dose selection of $\mathrm{C}$. borivilianum root extract was decided on the basis of previously performed experiments in our own laboratory (Kumar et al., 2010). Among the doses $800 \mathrm{mg} / \mathrm{kg}$ b.wt./day was selected for the study.

\subsection{ABTS radical cation decolorization assay}

The 2, 2 azinobis (3-ethylbenzothiazoline-6-sulfonic acid) radical cation (ABTS) decolorization test was used to assess the antioxidant activity of root extract. The ABTS assay was carried out using the improved assay of Re et al., (1999). $\mathrm{ABTS}^{-+}$was generated by oxidation of ABTS with potassium persulphate. ABTS was dissolved in deionized water at a concentration of $7 \mathrm{mM}$ concentration and potassium persulphate was added to a concentration of $2.45 \mathrm{mM}$. The reaction mixture was left to stand at room temperature overnight (12-16 h) in the dark before use. For the study of root extract, the $\mathrm{ABTS}^{-+}$solution was diluted with ethanol, to an absorbance of $0.700 \pm 0.020$ at $734 \mathrm{~nm}$. After addition of $1 \mathrm{ml}$ of diluted of ABTS solution to $10 \mu \mathrm{l}$ of root extract, the absorbance reading was taken at $30^{\circ} \mathrm{C}$ exactly $1 \mathrm{~min}$ after initial mixing and up to 6 min and study was carried out in triplicate. Ascorbic acid was taken as positive control.

\subsection{Experimental design}

Mice selected from inbred colony were divided into 4 groups such as

Group I (Control group): - Animals received double distilled water (DDW) as vehicle orally for 30 days.

Group II (C. borivilianum root extract treated group):- Root extract dissolved in DDW was administered orally for 30 days at 800 $\mathrm{mg} / \mathrm{kg}$ b.wt/day.
Group III (Sodium arsenite treated group):- Sodium arsenic dissolved in DDW was administered orally for 30 days at $4 \mathrm{mg} / \mathrm{kg} \mathrm{b}$. wt/day.

Group IV (Combination group): - C. borivilianum root extract was administered orally for 10 days. On the $11^{\text {th }}$ day, sodium arsenite and root extract both were given up to 30 days orally.

The animals from all the groups were weighted and sacrificed at 1 , $3,7,15,30$ days. Testis were removed, blotted and processed for biochemical assays.

\subsection{Biochemical studies}

\subsubsection{Total protein}

Total protein content in the testes was estimated by Lowry et al., (1951) method. Here, protein is precipitated with trichloroacetic acid. When Folin Ciocalteu reagent (Phosphatungstic phosphomolybdic acid) is added, a complex result, the intensity of which accounts for the amount of proteins present in tissue. Reading was taken at $640 \mathrm{~nm}$. Protein content was expressed as $\mathrm{mg}$ of protein/g of tissue.

\subsubsection{Sialic acid}

Sialic acid in the testes was estimated by the method of Svennerholm, (1960) as given by Glick. The principle involved depends on the fact that sialic acid (neuraminic acids) exhibit purple color in an acidic medium with resorcinol. Reading was taken at $580 \mathrm{~nm}$ (Green Filter) against the blank. Sialic acid content was expressed as $\mathrm{mg}$ of sialic acid/g of tissue.

\subsubsection{Adenosine triphosphatase (ATPase)}

For quantitative analysis of the activity of ATPase, the method given by Sickevitz and Potter, (1953) was followed. Tissues were homogenized in sucrose. Disodium salt of ATP was used as substrate. The activity was measured in term of inorganic phosphorus liberated from the tissue as for the acid and alkaline phosphatases. The absorbance was read at $640 \mathrm{~nm}$.

\subsubsection{DNA estimation assay}

DNA was quantified by the method described by Ceriotti (1955). Testis was dissected out and a homogenate was prepared in glacial distilled water. Homogenate was taken in a centrifuge tube and 1 $\mathrm{ml}$ indole reagent was added. Then, $1 \mathrm{ml}$ of concentrated $\mathrm{HCl}$ was added. Thereafter chloroform treatment was given. The water layer was separated out from the organic layer by centrifugation. The intensity of yellow colour was measured at a green filter against a blank. The volume of DNA was calculated from the graph and then the quantity of DNA in the tissue was calculated in $\mu \mathrm{g} / \mathrm{mg}$ tissue.

\subsubsection{RNA estimation assay}

RNA was quantified by the method described in Ceriotti (1955). Testis was dissected out and a homogenate was prepared in glacial distilled water. The reaction mixture contained $5 \mathrm{ml}$ homogenate + $5 \mathrm{ml}$ orcinol $+5 \mathrm{ml}$ isoamyl alcohol. The upper coloured layer was separated and the intensity was measured against red filter. The concentration of RNA from standard graph was calculated and then the amount of tissue RNA was calculated in $\mu \mathrm{g} / \mathrm{mg}$ tissue. 2.5.6 Statistical analysis

The data were expressed as mean $\pm \mathrm{SE}$. The values at each autopsy interval for each experiment was compared with control, i.e. Control (Group I) vs C. borivilianum (Group II) /Arsenic (Group III); Arsenic (Group III) vs C. borivilianum +Arsenic + C. borivilianum (Group IV). Statistical significance between the groups was determined by Student's t-test (Ipsen and Feigl, 1979). The significance level was set at $\mathrm{P}<0.05$ (a), $\mathrm{P}<0.01$ (b) and $\mathrm{P}<$ $0.001(\mathrm{c})$. 


\section{Results}

\subsection{Antioxidant activity}

C. borivilianum root extract showed significant antioxidant activity in the ABTS decolorization assay. It scavenges ABTS free radicals effectively as evidenced by a decrease in the absorption up to 6 minutes. The extract showed $0.522 \pm 0.016$ inhibition of ABTS after 6 minutes (Figure 1).

\subsection{Body weight}

A highly significant $(p<0.001)$ decrease in body weight was observed in an arsenic treated group. Combined treatment of $\mathrm{C}$. borivilianum and arsenic showed a highly significant increase with respect to $\mathrm{NaAsO}_{2}$ intoxicated mice (Figure 2).

\subsection{Testis weight}

A highly significant $(\mathrm{p}<0.001)$ decrease in testis weight was observed in an arsenic treated group. Combined treatment of $\mathrm{C}$. borivilianum and arsenic showed a highly significant increase with respect to $\mathrm{NaAsO}_{2}$ intoxicated mice (Figure 3).

\subsection{Total protein}

A highly significant $(\mathrm{p}<0.001)$ decline was observed in the testicular protein level in arsenic intoxicated mice whereas combined treatment of C. borivilianum and arsenic showed a highly significant elevation in protein at all autopsy intervals with respect to $\mathrm{NaAsO}_{2}$ intoxicated mice (Figure 4).

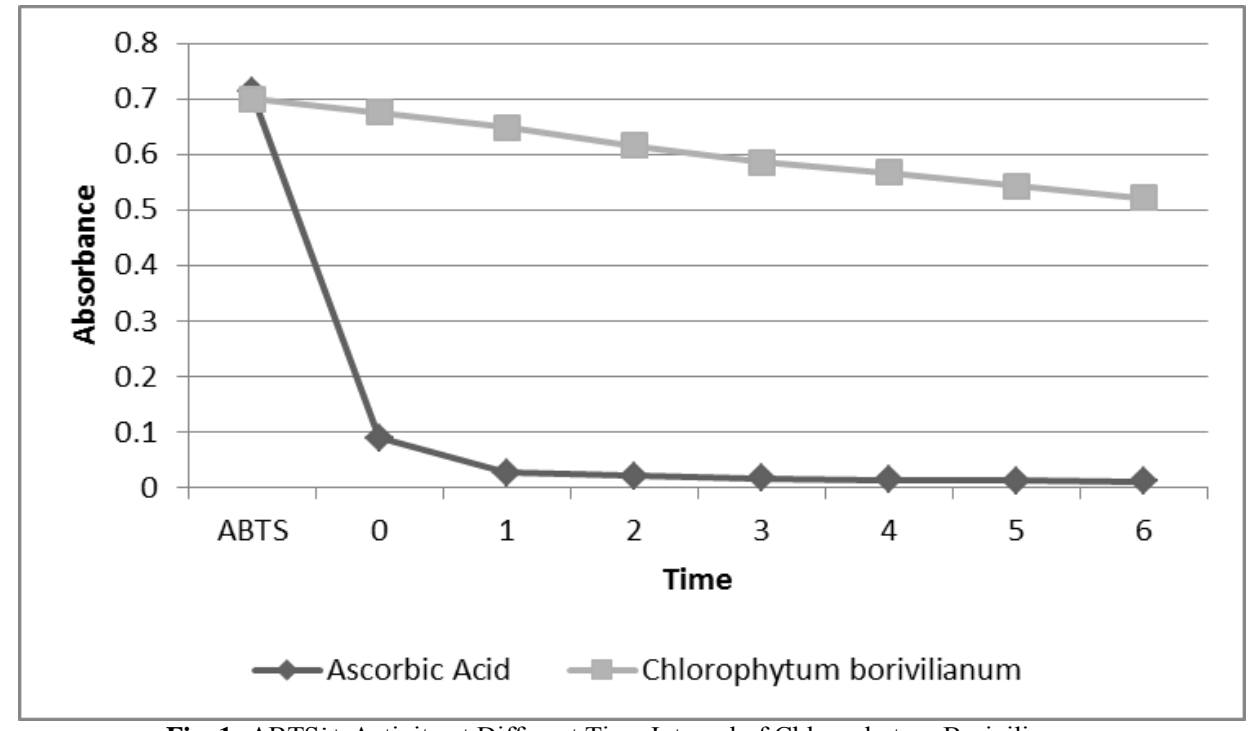

Fig. 1: ABTS + Activity at Different Time Interval of Chlorophytum Borivilianum.

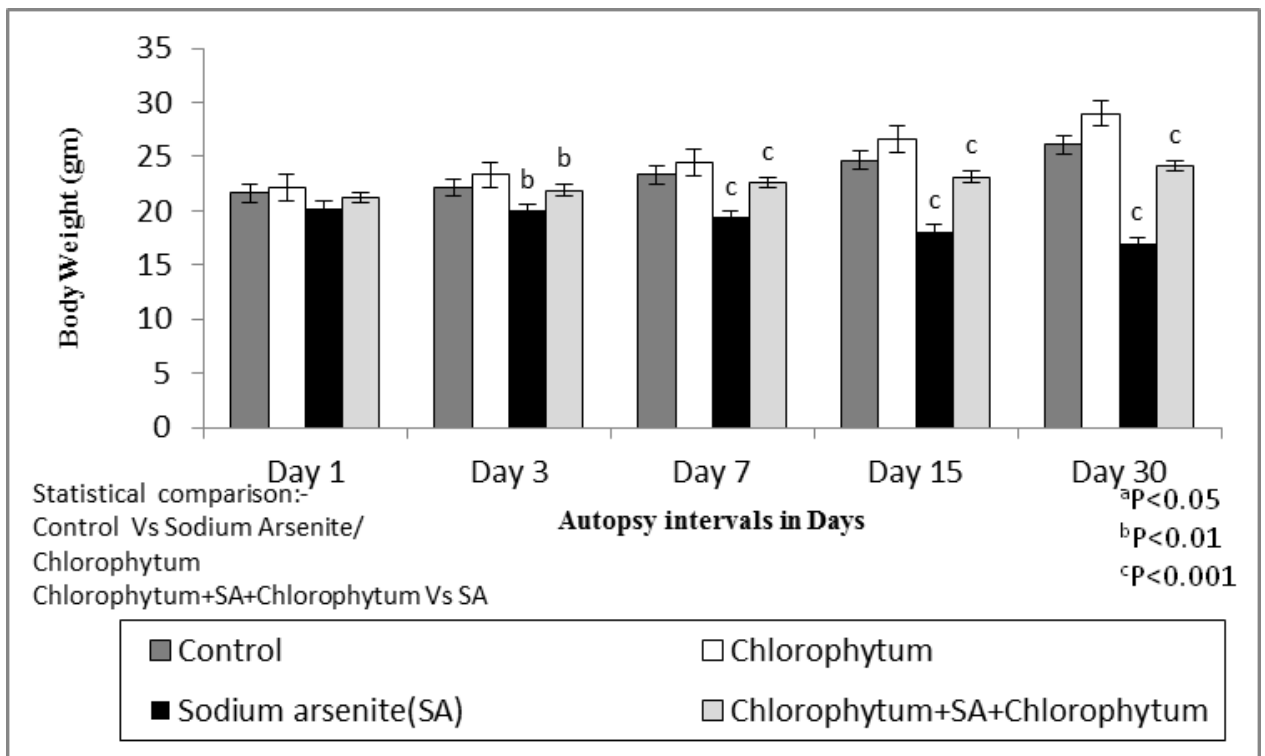

Fig. 2: Variation in Body Weight (in Gm.) of Male Swiss Albino Mice in Different Treated Groups. Significance Level Was Set at $\mathrm{P}<0.05(\mathrm{~A}), \mathrm{P}<$ $0.01(\mathrm{~B})$ and $\mathrm{P}<0.001(\mathrm{C})$. 


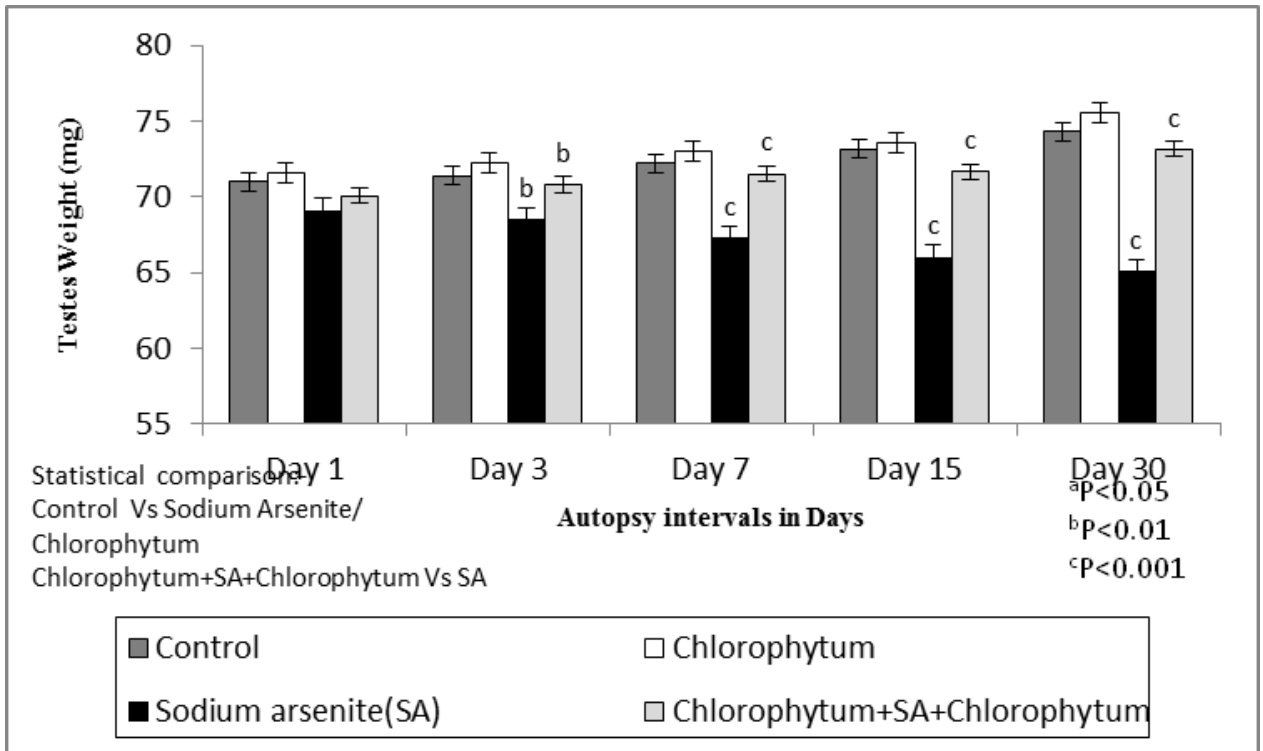

Fig. 3: Variation in Testis Weight (in Mg) of Male Swiss Albino Mice in Different Treated Group. Significance Level Was Set at $\mathrm{P}<0.05(\mathrm{~A}), \mathrm{P}<$ $0.01(\mathrm{~B})$ and $\mathrm{P}<0.001(\mathrm{C})$.

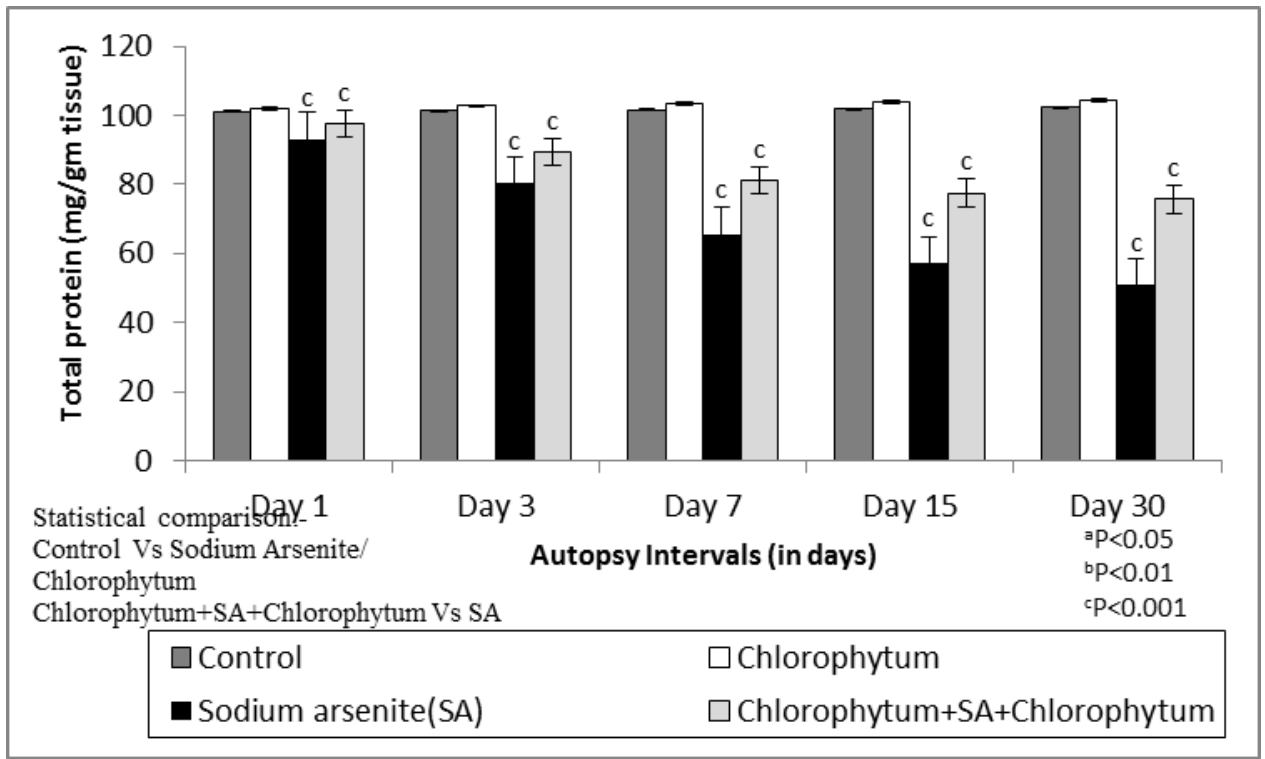

Fig. 4: Variation in Total Protein $(\mathrm{Mg} / \mathrm{Gm}$. Tissue) of Male Swiss Albino Mice in Different Treated Group. Significance Level was Set at $\mathrm{P}<0.05(\mathrm{~A})$, $\mathrm{P}$ $<0.01(\mathrm{~B})$ and $\mathrm{P}<0.001(\mathrm{C})$.

\subsection{Sialic acid}

A highly significant $(\mathrm{p}<0.001)$ decline was observed in the testicular sialic acid content in arsenic intoxicated mice whereas combined treatment of $\mathrm{C}$. borivilianum and arsenic showed a highly significant increase in sialic acid content with respect to sodium arsenite treated group (Figure 5).

\subsection{Adenosine triphosphatase (ATPase)}

The testicular activities of adenosine triphosphatase was significant $(p<0.001)$ declined after sodium arsenite treatment in comparison to control group. Co-administration of $\mathrm{C}$. borivilianum and arsenic showed a highly significant elevation in adenosine triphosphatase at all autopsy intervals with respect to arsenic intoxicated mice (Figure 6).

\subsection{DNA}

A highly significant $(\mathrm{p}<0.001)$ decline was observed in DNA in arsenic intoxicated mice as compared to control group. Combined treatment of $\mathrm{C}$. borivilianum and arsenic showed a highly signifi- cant elevation in DNA at all autopsy intervals with respect to $\mathrm{NaAsO}_{2}$ intoxicated mice (Figure 7).

\subsection{RNA}

A highly significant $(\mathrm{p}<0.001)$ decline was observed in RNA in arsenic intoxicated mice as compared to control group. Combined treatment of $\mathrm{C}$. borivilianum and arsenic showed a highly significant elevation in RNA at all autopsy intervals with respect to $\mathrm{NaAsO}_{2}$ intoxicated mice (Figure 8). 


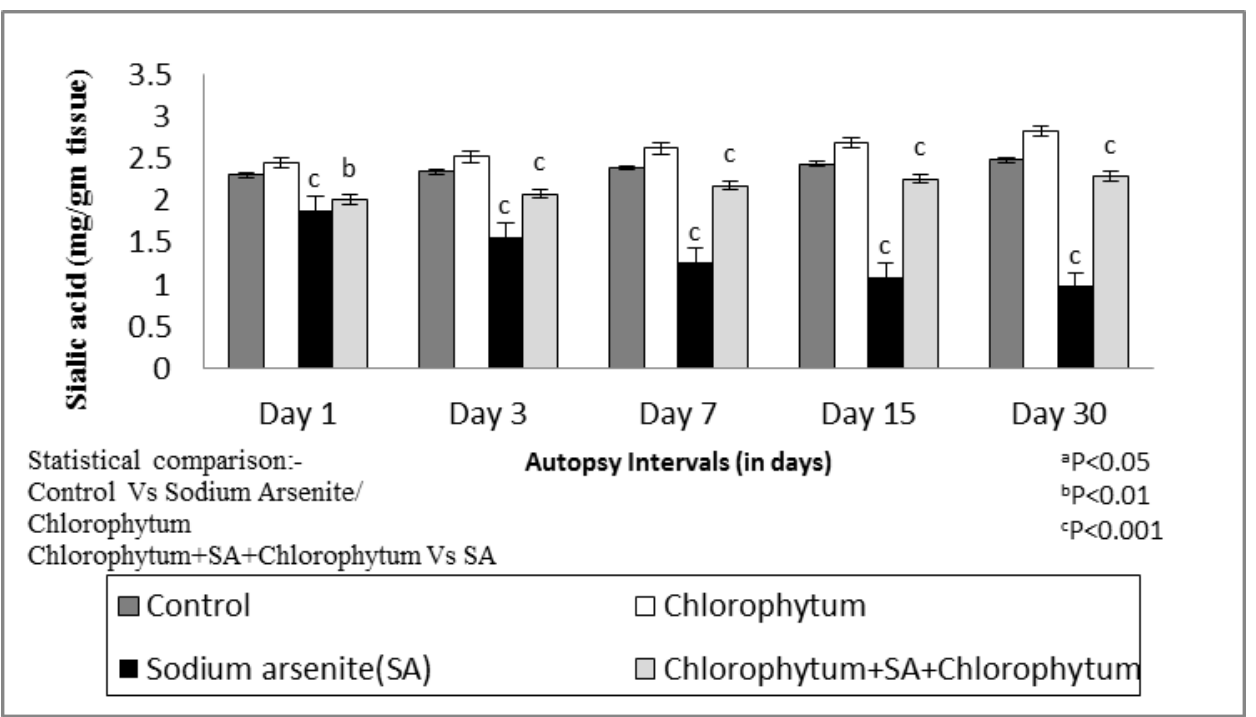

Fig. 5: Variation in Sialic Acid (Mg/Gm. Tissue) Of Male Swiss Albino Mice in Different Treated Group. Significance Level was Set At $\mathrm{P}<0.05$ (A), $\mathrm{P}<$ $0.01(\mathrm{~B})$ and $\mathrm{P}<0.001(\mathrm{C})$.

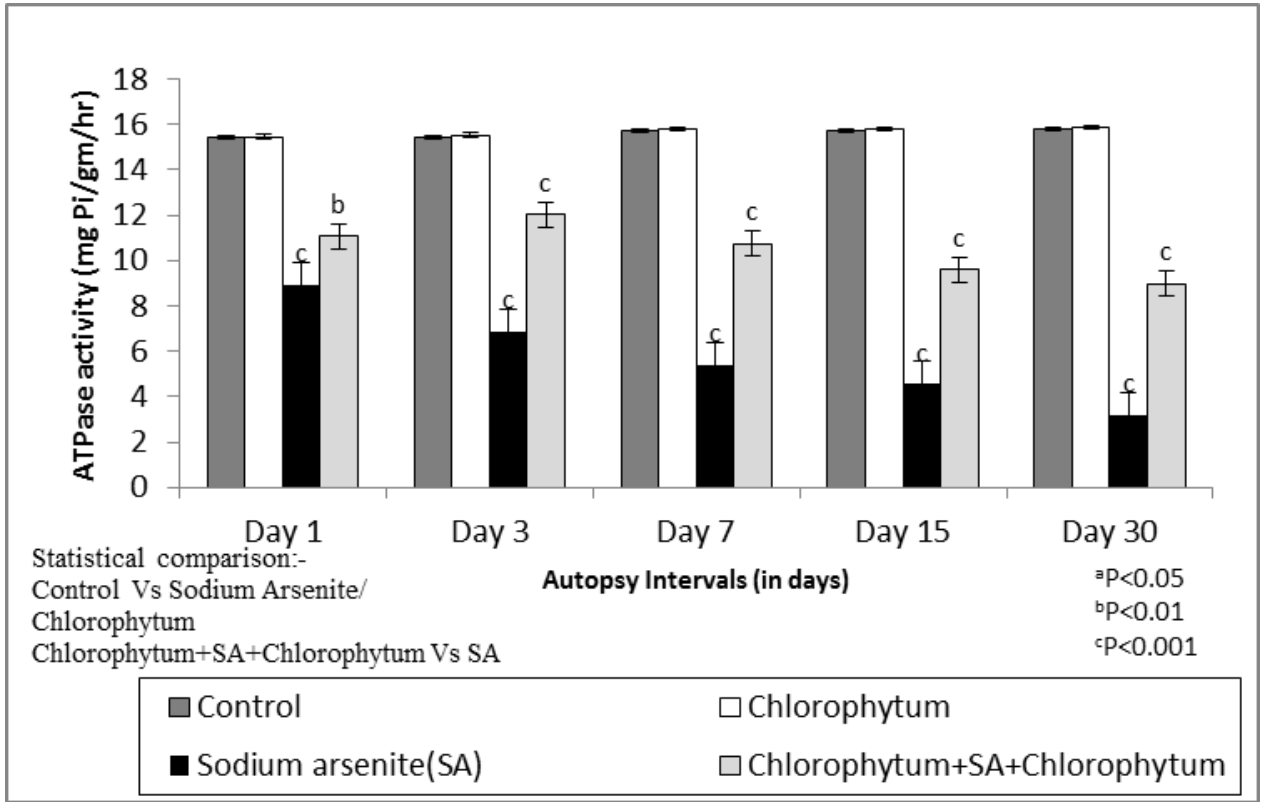

Fig. 6: Variation in Atpase Activity (Mg Pi/Gm. /Hr.) of Male Swiss Albino Mice in Different Treated Group. Significance Level Was Set at P < 0.05(A), $\mathrm{P}<0.01(\mathrm{~B})$ and $\mathrm{P}<0.001(\mathrm{C})$.

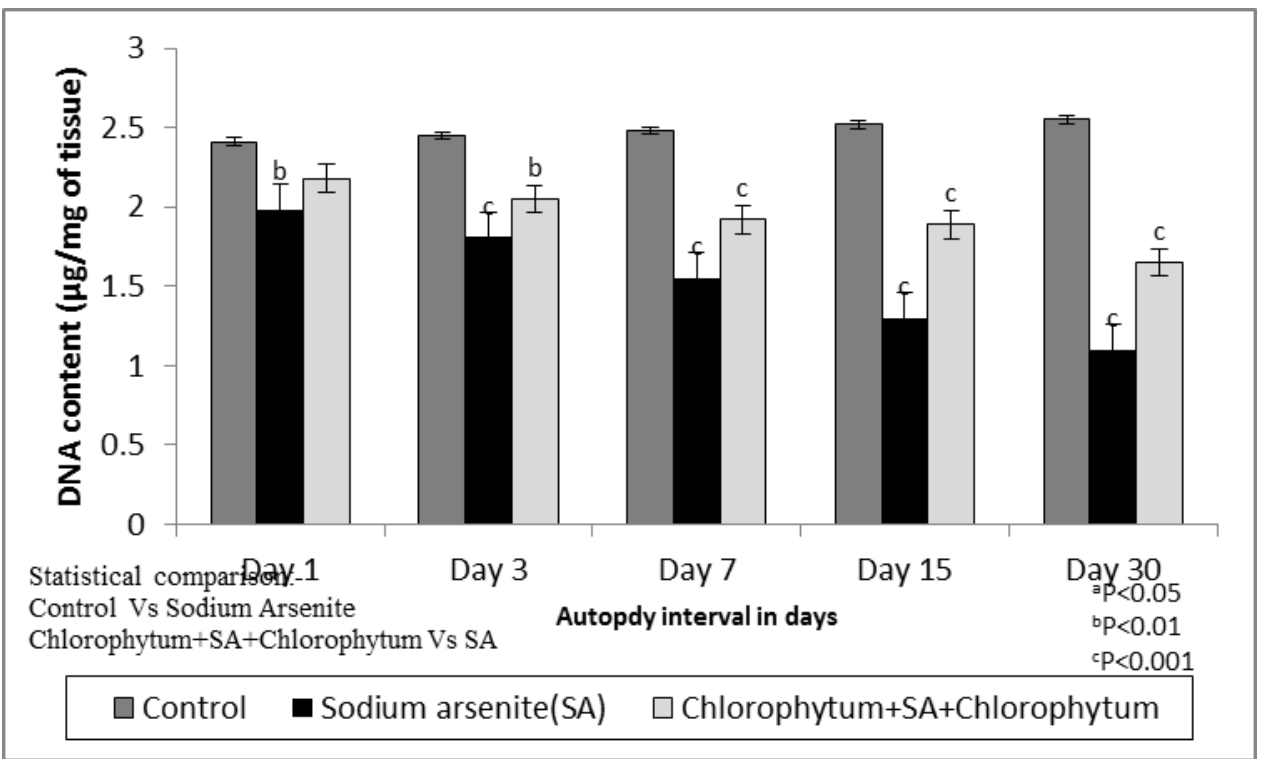

Fig. 7: Variation in the DNA Content (Mg/Mg of Tissue) in the Testis of Swiss Albino Mice in Different Treated Groups. 


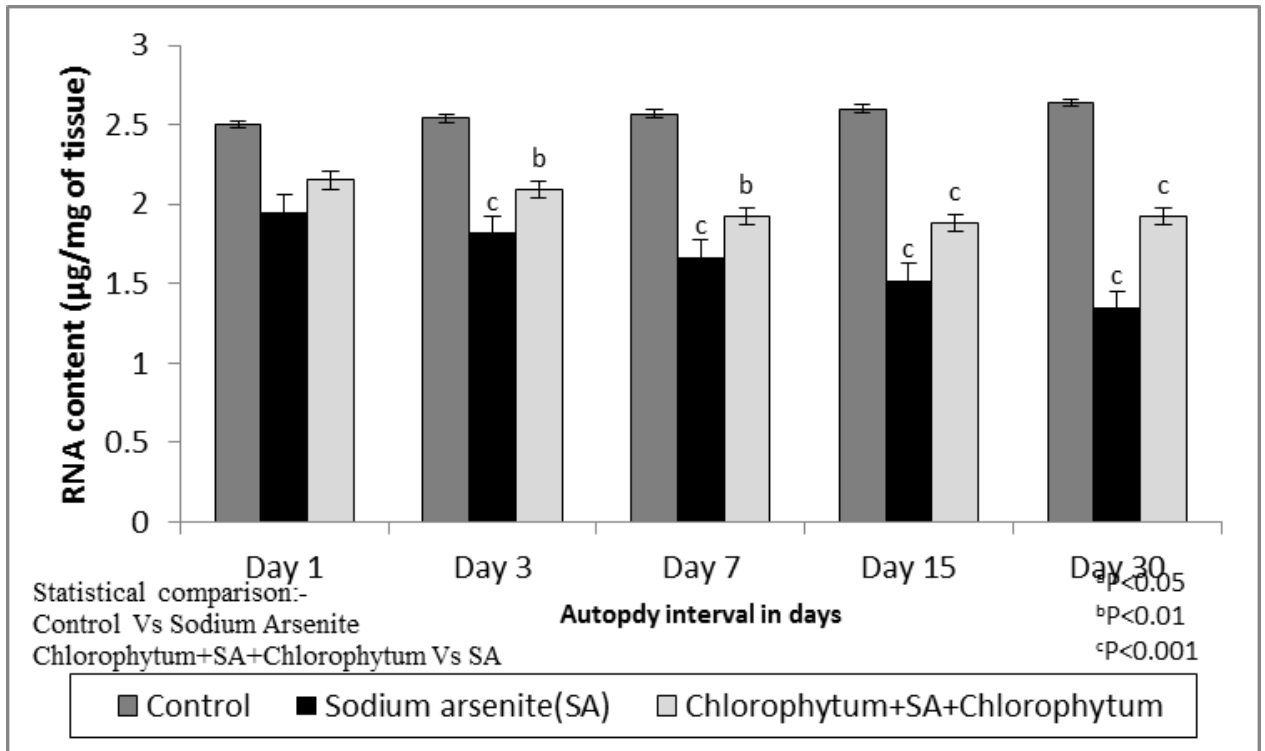

Fig. 8: Variation in the RNA Content (Mg/Mg of Tissue) in the Testis of Swiss Albino Mice in Different Treated Groups

\section{Discussion}

In the present study oral administration of $\mathrm{NaAsO}_{2}$ for 30 days to mice brought about a significant reduction in the body and testicular weight which may be due to cellular regression of tissue. This observation is in corroboration with the earlier finding of Sanghamitra et al., (2008). Testicular weight is a valuable index of reproductive toxicity and the decrease in testis weight was consistent with damage and elimination of germ cells (Sharma and Kumar, 2011; Chapin and Lamb, 1984).

In the present study, protein content depicted a highly significant decline after sodium arsenite administration. This decline might be due to the destructive action of arsenic on tissue and enzymatic activity. Our study is in support with Wang et al., (2006) who reported that arsenic treatment showed decreased protein levels in the testes. The toxicity of arsenic arises in part from its electrophilic nature, as arsenite binds to electron-rich sulfhydryl groups on proteins, which modulates protein activity (Squibb and Fowler, 1983; Chang et al., 2007). As the protein constitutes one of the major components of tissue weight, the alteration in the tissue protein and their synthesis are responsible for the changes in the weight of tissue. Reactive oxygen species increases lipid peroxidation; modulation of intracellular oxidized states, DNA damage, membrane damage; all these altered the protein expression and apoptosis (Chang et al., 2007; Stohs et al., 2000).

In the present study, a highly significant decline in sialic acid content was observed in testis on exposure to arsenic. Sialic acid is an important molecule found on the cell surface as secreted glycoconjugates. It is present in the spermatids and spermatozoa and essential for the maintenance of the structural integrity of sperm membrane and sperm maturation (Chinoy et al., 1994). Mann (1964) reported that the sialic acid concentration in the testes declined with the decrease in the rate of spermatogenesis. The impaired spermatogenesis and fertility of arsenic treated animal may partly be due to low level of sialic acid and the associated changes in sperm maturation. It is established that arsenic induce a germ cell depletion (Jana et al., 2006; Manna et al., 2008) and decrease in the sialic acid concentration may be due to the degenerative changes in the testis.

ATP loss causes deleterious effects on sperm morphology and viability. In the present study, a highly significant decline in ATPases was observed in testis on exposure to arsenic. Most toxicants interact with the intracellular target molecules and cell membrane, change the cellular metabolism and functions that lead to membrane damage and lysis. Ramalingam \& Vimaladevi, (2002) reported that metals generally inhibit the function of ion dependent ATPases leading to disturbances in the ion homeostasis which results in impaired signal transduction, altered cellular me- tabolism, changes in cell membrane permeability and integrity, and disturbances of vital function. Arsenic inhibits pyruvate dehydrogenase by binding to the sulfydryl groups of dihydrolipoamide, resulting in a reduced conversion of pyruvate to acetyl coenzyme A $(\mathrm{CoA})$, while both citric acid cycle activity and production of cellular ATP are decreased (Bergquist et al., 2009). Uncoupling of oxidative phosphorylation occurs because of the lack of formation of high energy phosphate bonds. In the presence of pentavalent arsenic, adenosine diphosphate (ADP) forms ADP arsenate instead of ATP, with the absence of the high energy ATP phosphate bonds (Jomova et al., 2011).

In the present study, DNA content was found to decrease in the arsenic treated group as compared to control group. Our observation demonstrated that free radicals might be involved in arsenic induced DNA damage. ROS are involved in chromosomal aberrations, gene mutation (Hei et al., 1998), DNA strand breakage (Lynn et al., 2000), generation of micronuclei (Wang and Huang, 1994) and apoptosis (Gurr et al., 1999). Metabolism of arsenic generates oxygen radicals (Valko et al., 2006) which may damage the cellular macromolecules and decrease cytP450 biotrasformation enzymes involved in xenobiotic metabolism (Albores et al., 1989). These ROS damage DNA directly or indirectly, induces DNA adducts and inhibition of the DNA repair process (Barstch and Nair, 2000), damage to bases and the sugarphosphates, as well as single-or double-strand breaks within DNA. Moreover, the reactive aldehydes such as MDA and 4hydroxyalkenals that are derived from the peroxidized phospholipids by ROS and free radicals can also react with DNA and causes several damage by forming exocyclic DNA adducts (Johari et al., 2011). The decrease in DNA contents could also be attributed to the inhibition of DNA synthesis.

In the present study RNA content was significantly decreased in arsenic treated mice testis as compared to control group that might be partly due to diminished DNA content and inhibited transcription. Any damage inflicted on DNA molecule further results in the diminished RNA contents and suppressed the protein expression within the organism (Johari et al., 2011). These findings indicate that exposure to toxic metals affects primary spermatocyte DNA and are suggestive of possible direct testicular toxicity. Significant DNA damage was found in primary spermatocytes from rats with chronic exposure to toxic metals such as arsenic trioxide (NavaHernández et al., 2009).

The aqueous root extract of $\mathrm{C}$. borivilianum produces significant $\%$ inhibition at the level of ABTS free radical that shows its antioxidant potential. This study is in support of Visavadiya et al., (2010). The herbs have been traditionally used as Vajikaran Rasayana herbs because of their putative positive influence on sexual performance in humans (Chakraborthy and Aeri, 2008). C. 
borivilianum contains proteins (8-9\%), carbohydrates $(41 \%)$, root fibers $(4 \%)$, saponins $(2-17 \%)$, minerals and vitamins. Saponins and alkaloids present in the plant are the primary source of its significant medicinal properties. The root is a rich source of pharmaceutical active compounds like steroids, glycosides, spirostanosides and phenols (Thakur et al., 2009(a).

In the present study increased body weight and testicular weight in combination group is due to the antioxidant activity of $\mathrm{C}$. borivilianum against oxidative damage induced by arsenic. Coadministration of arsenite and $\mathrm{C}$. borivilianum restored the reproductive organ indices towards normal which may be due to its androgenic activity (Jana et al., 2006). Improvement in body weight is generally attributed to steroidogenesis and is a biological indicator of the effectiveness of the herbal drugs in improving the genesis of steroidal hormones (Chakraborthy and Aeri, 2008).

Due to the antioxidant activity of $\mathrm{C}$. borivilianum, it decreases lipid peroxidation, maintains cell membrane integrity, recovers germ cell population and maintains the level of protein, sialic acid and ATPase and protects the DNA and RNA content in the combination group. The overall constitution of aqueous root extract rich in steroidal saponin and fructo-oligosaccharide provides a prototype combination for combating the degenerative influence on sexual function caused by ROS (Thakur et al., 2009(a). The saponins in the roots are aphrodisiac, adaptogenic, antiaging, health restorative, health promoting (Vijaya and Chavan, 2009) and shows spermatogenic property and is found beneficial in curing impotency.

\section{Conclusion}

Thus the present study concludes that arsenic induced testicular toxicity may be alleviated by $\mathrm{C}$. borivilianum root extract, which is reflected by elevation in total protein, sialic acid, ATPase activity, DNA and RNA content with maintaining spermatogenesis in Swiss albino mice.

\section{Acknowledgement}

Authors are gratefully acknowledged to the UGC New Delhi for providing financial assistance to Garima Sharma as Junior Research Fellow, Letter No. F-41-4/NET/RES/JRF-699.

\section{Conflict of interest statement}

There is no conflicting interest.

\section{References}

[1] Albores A, Cebrian ME, Bach PH, Connelly JC, Hinton RH \& Bridges JW (1989) Sodium arsenite induced alterations in bilirubin excretion and heme metabolism. Journal of Biochemical Toxicology 4, 73 78. http://dx.doi.org/10.1002/jbt.2570040202.

[2] Ali S \& Ali S (2010) Genetic integrity of the human Y chromosome exposed to groundwater arsenic. BMC Medical Genomics 3, 35. http://dx.doi.org/10.1186/1755-8794-3-35.

[3] Barstch H \& Nair J (2000) Ultra-sensitive and specific detection methods for exocyclic DNA adducts: markers for lipid peroxidation and oxidative stress. Toxicology 153, 105-114. http://dx.doi.org/10.1016/S0300-483X(00)00307-3.

[4] Bergquist ER, Fischer RJ, Sugden KD \& Martin BD (2009) Inhibition by methylated organo-arsenicals of the respiratory 2-oxo-acid dehydrogenases. Journal of Organometallic Chemistry 694, 973-980. http://dx.doi.org/10.1016/j.jorganchem.2008.12.028.

[5] Biswas NM, Chowdhury RG \& Sarkar M (1994) Effects of sodium arsenite on adrenocortical activities in male rats. Dose-duration dependent responses. Medical Science Research 23, 153-154.

[6] Ceriotti G (1955) A microchemical determination of deoxyribonucleic acid. Journal of Biological Chemistry 198, 297-303.

[7] Chakraborthy GS \& Aeri V (2008) Antidiabetic and antihyperlipidaemic effect of alcoholic extract of Chlorophytum borivilianum roots in alloxan induced diabetic albino rats. Journal of Pharmacy Research 1, 29-33.

[8] Chang SI, Jin B, Youn P, Park JD \& Ryu DY (2007) Arsenic-induced toxicity and the protective role of ascorbic acid in mouse testis. Toxicology and Applied Pharmacology 218, 196-203 http://dx.doi.org/10.1016/j.taap.2006.11.009.

[9] Chapin RE \& Lamb JC (1984). Effect of ethylene glycol monoethyl ether on various parameters of testicular function in the F344 rats. Environmental Health Perspectives 57, 219-224. http://dx.doi.org/10.1289/ehp.8457219.

[10]Chetty KM \& Rao KN (1989) Ethnobotany of Sarakallu and adjacent areas of Chittoor district. Vegetos 2, 51 .

[11]Chinoy NJ, Reddy WIC \& Michael M (1994) beneficial effects of ascorbic acid and calcium on reproductive functions of sodium flouride treated male rats. Flouride 27, 71-79.

[12]Erbanova L, Novak M, Fottova D \& Dousova B (2008) Export of arsenic from forested catchments under easing atmospheric pollution. Environmental Science and Technology 42(19), 7187-7192. http://dx.doi.org/10.1021/es800467j.

[13]Gopalkrishnan a \& Rao MV (2006) Amelioration by vitamin A upon arsenic induced metabolic and neurotoxic effects. Journal of Health Science 52, 568-577. http://dx.doi.org/10.1248/jhs.52.568.

[14]Guha Mazumder DN (2008) chronic arsenic toxicity \& human health. Indian Journal of Medical Research 128, 436-447.

[15]Gurr JR, Bau DT, Liu F, Lynn S \& Jan KY (1999) Dithiothreitol enhances arsenic trioxide induced apoptosis in NB4 cells. Molecular Pharmacology 56,102-109.

[16]Hei TK, Liu SX \& Waldren C (1998) Mutagenecity of arsenic in mammalian cells: Role of reactive oxygen species. Proceedings of the National Academy of Sciences 95, 8103-8107. http://dx.doi.org/10.1073/pnas.95.14.8103.

[17]Ipsen J \& Feigl P (1979) Bancrofts Introduction to Biostatistics. 2nd Edn, Harper and Row Publishers, New York, Franston and London.

[18]Jana K, Jana S \& Samanta PK (2006) Effect of chronic exposure to sodium arsenite on hypothalamo-pituitary-testicular activities in adult rats: Possible on estrogenic mode of action. Reproductive Biology and Endocrinology 4 (9), 1- 13.

[19]Johari P, Kumar M \& Kumar A (2011) Oltipraz: DNA and RNA Protection. Pharmacologyonline 1, 651-659.

[20]Jomova K, Jenisova Z, Feszterova M, Baros S, Liska J, Hudecova D, Rhodes CJ \& Valko M (2011) Arsenic: Toxicity, oxidative stress and human disease. Journal of Applied Toxicology 31, 95-107.

[21] Kaushik N (2005) Saponins of chlorophytum species. Phytochemistry Reviews 4, 191-196. http://dx.doi.org/10.1007/s11101-005-2607-5.

[22] Klein CB, Leszczynska J, Hickey C \& Rossman TG (2007) further evidence against a direct genotoxic mode of action for arsenic-induced cancer. Toxicology and Applied Pharmacology 222(3), 289-297. http://dx.doi.org/10.1016/j.taap.2006.12.033.

[23] Kokilavani V, Devi MA, Sivarajan K \& Panneerselvam C (2005) Combined efficacies of $\alpha$-lipoic acid and meso 2, 3 dimercaptosuccinic acid against arsenic induced toxicity in antioxidant systems of rats. Toxicology Letters 160, 1-7. http://dx.doi.org/10.1016/j.toxlet.2005.05.018.

[24]Kumar M, Meena P, Verma S, Kumar M \& Kumar A (2010) Antitumor, anti-mutagenic and chemomodulatory potential of Chlorophytum borivilianum. Asian Pacific Journal for Cancer Prevention 11, 327-334.

[25]Lowry GH, Resebrough MJ, Farr AL \& Randall RR (1951) Protein measurement with the Folin phenol reagent. Journal of Biology Chemistry 193, 265- 275 .

[26]Lynn S, Gurr JR, Lai HT\& Jan KY (2000) NADH oxidase activation is involved in arsenite-induced oxidative DNA damage in human vascular smooth muscle cells. Circulation Research 86, 514-519. http://dx.doi.org/10.1161/01.RES.86.5.514.

[27]Mann T (1964) Biochemistry of the Semen and the Male Reproductive Tract. John Wiley and Sons. Inc. London.

[28] Manna P, Sinha M \& Sil PC (2008) Protection of arsenic induced testicular oxidative stress by arjunolic acid. Redox Report 13(2), $67-$ 77. http://dx.doi.org/10.1179/135100008X259169.

[29] Nava-Hernández MP, Hauad-Marroquín LA, Bassol-Mayagoitia S, García-Arenas G, Mercado-Hernández R, Echávarri-Guzmán MA \& Cerda-Flores RM (2009) Lead-, Cadmium-and Arsenic-Induced DNA Damage in Rat Germinal Cells. DNA Cell Biology 28(5), 241-248. http://dx.doi.org/10.1089/dna.2009.0860.

[30]Patwardhan B, Warude D, Pushpangadan P \& Bhatt N (2005) Ayurveda and traditional Chinese medicine: a comparative overview. Ecam 2, 465-73.

[31]Peltola V, Montyla E, Hutaniemi I \& Ahutupa M (1994) Lipid peroxidation and antioxidant enzyme activities in the testis cigarette smoke 
inhalation or administration of polychlorinated biphenyls or polychlorinated napthalenes. Journal of Andrology 15, 353.

[32]Ramalingam V \& Vimaladevi V (2002) Effect of mercuric chloride on membrane-bound enzymes in rat testis. Asian Journal of Andrology 4 309-311.

[33]Re R, Pallegrini N, Proteggente A, Pannala A \& Yang M (1999) Rice Evans, C. Free Radical Biology and Medicine 26, 1231-1237. http://dx.doi.org/10.1016/S0891-5849 (98)00315-3.

[34]Robertson RP, Harmon J, Tran PO, Tanaka Y \& Takahashi H (2003) Glucose toxicity in cells: type- 2 diabetes, good radicals gone bad and the glutathione connection. Diabetes 52, 581-587. http://dx.doi.org/10.2337/diabetes.52.3.581.

[35] Sanghamitra S, Hazra J, Upadhyay SN, Singh RK \& Chowdhury R (2008) Arsenic induced toxicity on testicular tissue of mice. Indian Journal of Physiology Pharmacology 52(1), 84-90.

[36]Santra A, Chowdhury A, Ghatak S, Biswas a \& Dhali GK (2007) Arsenic induces apoptosis in mouse liver is mitochondria dependen and is abrogated by $\mathrm{N}$-acetylcysteine. Toxicology and Applied Pharmacology 220, 146-155. http://dx.doi.org/10.1016/j.taap.2006.12.029.

[37]Sarkar M, Biswas NM \& Ghosh D (1991) Effect of sodium arsenite on testicular and 3beta and 17beta hydroxysteroid dehydrogenase activation in albino rats: dose and duration dependent response. Medical Science and Research 19, 789-793.

[38]Sarkar M, Chaudhuri GR, Chattopadhyay \& a Biswas NM (2003) Effect of sodium arsenite on spermatogenesis, plasma gonadotrophins and testosterone in rats. Asian Journal of Andrology 1, 27-31.

[39]Sharma A, Sharma MK \& Kumar M (2009) Modulatory role of Emblica officinalis fruit extract against arsenic induced oxidative stress in Swiss albino mice. Chemico-Biological Interactions 180, 20 30. http://dx.doi.org/10.1016/j.cbi.2009.01.012.

[40]Sharma G \& Kumar M (2011) Morphometrical study of seminiferous tubules of mice after using arsenic and Chlorophytum borivilianum. Pharmacologyonline 2, 348-359.

[41] Sharma G \& Kumar M (2012) Antioxidant and modulatory role of Chlorophytum borivilianum against arsenic induced testicular impairment. Journal of Environmental Science 24(12), 2159-2165. http://dx.doi.org/10.1016/S1001-0742 (11)61019-X.

[42]Siekevitz P \& Potter VR (1953) the adenylate kinase of the rat liver mitochondria. Journal of Biological Chemistry 200, 187-196.

[43] Squibb KS \& Fowler BA (1983) the toxicity of arsenic and its compounds. In: Fowler, B.A. (Ed.), Biological and Environmental Effects of Arsenic. Elsevier, Amsterdam, 233-242. http://dx.doi.org/10.1016/B978-0-444-80513-3.50011-6.

[44]Stohs SJ, Bagchi D, Hassoun E \& Bagchi M (2000) Oxidative mechanisms in the toxicity of chromium and cadmium ions. Journal of Environmental Pathology, Toxicology and Oncology 19, 201-213.

[45]Svennerholm L (1960) Isolation and determination of neuraminic (sialic) acid by resorcinol reaction. In Methods of Biochemical Analysis, Glick D (Ed.), Interscience, New York 8, 214-215.

[46] Thakur M \& Dixit VK (2008) A review on some important medicinal plants of Chlorophytum spp. Pharmacognosy Review 2(3), 168-172.

[47]Thakur GS, Bag M, Sanodiya BS, Debnath M, Zacharia A Bhadauriya P, Prasad GB \& Bisen PS (2009) Chlorophytum borivilianum: a white gold for biopharmaceuticals and neutraceuticals. Current Pharmaceutical Biotechnology 10(7), 650-666 http://dx.doi.org/10.2174/138920109789542084.

[48] Thakur M, Bhargava S, Sharma V, Loeppert R, Praznik W \& Dixi VK (2009(a) Effect of Chlorophytum borivilianum Sant. and F. on sexual dysfunction in hyperglycemic male rats. Chinese Journal of Integrative Medicine 15, 448-453. http://dx.doi.org/10.1007/s11655 009-0448-6.

[49] Valko M, Rhodes CJ, Moncol J, Izkovic M \& Mazur M (2006) Free radicals, metals and antioxidants in oxidative stress-induced cancer. Cancer Research 160, 1-40.

[50]Vijaya KN \& Chavan PD (2009) Chlorophytum borivilianum (Safedmusli): A review. Pharmacognosy Reviews 3(5), 154-169.

[51]Visavadiya NP, Soni B, Dalwadi N \& Madamwar D (2010) Chlorophytum borivilianum as potential terminator of free radicals in various in vitro oxidation systems. Drug and Chemical Toxicology 33(2), 173-182. http://dx.doi.org/10.3109/01480540903311068.

[52]Vizcaya-Ruiz AD, Barbier O, Ruiz-Ramos R \& Cebrian ME (2009) Biomarkers of oxidative stress and damage in human populations exposed to arsenic. Mutational Research 674, 85-92. http://dx.doi.org/10.1016/j.mrgentox.2008.09.020.

[53]Wang TS \& Huang H (1994) Active oxygen species are involved in the induction of micronuclei by arsenite in XRS-5 cells. Mutgenesis 9 253-257. http://dx.doi.org/10.1093/mutage/9.3.253.

[54]Wang A, Holladay S, Wolf DC, Ahmed SA \& Robertson JL (2006) Reproductive and developmental toxicity of arsenic in rodents: A Re- view. International Journal of Toxicology 25, 319-331. http://dx.doi.org/10.1080/10915810600840776. 